\title{
Major mountain cedar allergen, Jun a 1, contains conformational as well as linear IgE epitopes
}

\author{
Shikha Varshney ${ }^{\mathrm{a}, \mathrm{b}}$, Randall M. Goldblum ${ }^{\mathrm{a}}$, Christopher Kearney $^{\mathrm{b}}$, Masanao Watanabe ${ }^{\mathrm{c}}$, and \\ Terumi Midoro-Horiutia, ${ }^{*}$ \\ a Department of Pediatrics, Child Health Research Center, University of Texas Medical Branch, 301 \\ University Blvd., Galveston, TX 77555-0366, USA \\ b Department of Biology, Biomedical Studies Program, Baylor University, One Bear Place \#7388, Waco, TX \\ 76798, USA \\ c Tokyo Research Laboratories, Kowa Co. Ltd., 2-17-43 Noguchi-cho, Higashi-Murayama, Tokyo 189-0022, \\ Japan
}

\section{Abstract}

We have previously identified four linear IgE epitopes on Jun a 1, the dominant allergen in mountain cedar pollen and mapped these to the surfaces of a molecular model and to the crystal structure of this glycoprotein. The aim of the present study was to determine if Jun a 1 also displays conformational IgE epitopes. Jun a 1 was denatured by heating at $75^{\circ} \mathrm{C}$ for $1 \mathrm{~h}$, exposure to $6 \mathrm{M}$ guanidine or by reductive alkylation in the presence and absence of guanidine. The effects of these manipulations on the binding to IgE from patients with mountain cedar hypersensitivity was evaluated by an ImmunoCAP inhibition assay, using Jun a 1-specific caps. Treatment-associated changes in the 3D-structure were assessed by dynamic light scattering and CD spectroscopy. IgE binding to native Jun a 1 was inhibited $92 \pm 9 \%$ by soluble native protein and $92 \pm 9 \%$ by reduced and alkylated Jun a 1. However, the capacity of Jun a 1 to inhibit the binding of IgE antibodies was significantly diminished upon denaturation by heat, guanidine alone, or reduction and alkylation in guanidine, compared to native Jun a 1. Reductive alkylation treatment under denaturing conditions also increased the Stoke's radius, suggesting that the protein was partially unfolded. Analysis of the circular dichroism (CD) spectra suggested that heating and treatment with guanidine caused a loss of $\alpha$-helical structure. Guanidine also caused an increase in random coil structure. Thus, at least a portion of the anti-Jun a $1 \mathrm{IgE}$ antibodies produced by allergic humans recognize conformational epitopes and it is likely that some of these epitopes reside in $\alpha$-helical structures of Jun a 1.

\section{Keywords}

Allergen structure; Cedar pollen hypersensitivity; Conformational epitopes; Cry j 1; IgE epitope; Jun a 1; Juniperus ashei; Mountain cedar; Protein denaturation

\section{Introduction}

IgE-mediated hypersensitivity diseases represent a major and increasingly prevalent health problem in the industrialized world, affecting up to one-third of some populations (Law et al., 2003; Romagnani, 2004). The underlying allergic reactions are mediated by cross-linking of receptor-bound specific IgE antibodies on the surface of mast cells or basophils by otherwise 
harmless proteins, termed allergens. The epitopes recognized by IgE antibodies represent several different types of structural elements of the allergens. Continuous (linear) epitopes are defined as residing within of a row of consecutive amino acids, while discontinuous (conformational) epitopes are composed of amino acids from different portions of the allergen brought into proximity by the fold of the allergen. $\mathrm{IgE}$ antibodies can also recognize oligosaccharides or glycans, either as independent moieties or in association with the peptide region to which they are attached.

Structural integrity or conformation of a number of aeroallergens seems to be important for the binding of the human IgE antibodies that initiate allergic reactions (Lombardero et al., 1990; Vrtala et al., 1997). Grass pollen allergen Phl p 5b (Schramm et al., 2001), mite allergen Der f 2 (Takai et al., 1997) and cherry allergen Pru av 1 (Neudecker et al., 2003) lose their allergenic activities when they are denatured. The extent of surface exposure of the epitopes may also be important in allergic sensitization as in case of Bet v 1 (Gajhede et al., 1996) and velvet grass allergen Hol 15 (Schramm et al., 1996).

In certain allergen molecules, intra-molecular disulfide bonds are required to produce or maintain conformational IgE epitopes on the surface of the molecule (Scheiner and Kraft, 1995). For example disulfide bonds play an important role in IgE binding in the case of Der $\mathrm{p}$ 2 (Smith and Chapman, 1996) and grass allergen Lol p 1 (Weerd et al., 2003).

Mountain cedar (Juniperus ashei), Cupressaceae family is a major cause of seasonal hypersensitivity in the central US (Midoro-Horiuti et al., 2003; Reid et al., 1992). Jun a 1, which was cloned and characterized in our lab (Midoro-Horiuti et al., 1999a; Midoro-Horiuti et al., 1999b), is the major allergenic protein of the pollen of J. ashei (personal communication). Four linear IgE epitopes have been mapped on the surface of a model structure of Jun a 1 (Midoro-Horiuti et al., 2003) and recently confirmed on a high-resolution crystal structure (Czerwinski et al., 2005). The present study was undertaken to determine if Jun a 1 also has conformational IgE epitopes, the extent to which these are responsible for $\operatorname{IgE}$ binding and to look for clues concerning the structural basis for these epitopes.

\section{Materials and methods}

\subsection{Human sera and mouse monoclonal antibody (mAb)}

Five human sera were obtained from mountain cedar allergic patients from the Austin, Texas area. The diagnosis of seasonal allergic rhinitis due to cedar sensitivity was established in these subjects by clinical history, scratch testing with commercial extract of mountain cedar pollen (Hollister-Stier, Spokane, WA, Midoro-Horiuti et al., 1999a) and high IgE titer to Jun a 1 by ImmunoCAP (Pharmacia Diagnostics, Sweden). A mouse mAb (KW-S91) produced by immunization with Cry j 1, a homologue of Jun a 1 from Japanese cedar pollen was obtained from Kowa Co. Ltd. (Takahashi et al., 1993). We have recently shown that this antibody binds to a linear epitope of Jun a 1 (Midoro-Horiuti et al., 2006).

\subsection{Protein purification and quantification}

Jun a 1 was purified from mountain cedar pollen (Hollister-Stier, lot no. 0202615) using ConA Sepharose 4B (Pharmacia) chromatography, as previously described (Midoro-Horiuti et al., 1999a). The purified Jun a 1 was dialyzed against PBS (15 $\mathrm{Mm} \mathrm{NaCl}$ and $25 \mathrm{mM} \mathrm{KH}_{2} \mathrm{PO}_{4}-$ $\mathrm{K}_{2} \mathrm{HPO}_{4}$, pH 8.0) and the purity of Jun a 1 was established by Coomassie-stained SDS-PAGE. The protein concentrations were estimated by densitometry of the SDS-PAGE gels.

\subsection{Heat denaturation}

Purified Jun a 1 in PBS ( $\mathrm{pH} 8.0$ ) was denatured by heating in a $75^{\circ} \mathrm{C}$ water bath for $1 \mathrm{~h}$. 


\subsection{Reductive alkylation}

Reduction and alkylation of Jun a 1 was performed by a modification of the method of Imoto and Yamada (Imoto and Yamada, 1989; Yang et al., 2000). Purified Jun a $1(2.75 \mathrm{mg} / \mathrm{ml})$ in $1 \mathrm{ml} 0.5 \mathrm{M}$ Tris, $\mathrm{pH} 8.5$ with and without $6 \mathrm{M}$ guanidine $\mathrm{HCl}$ was reduced in the presence of $1.5 \mathrm{mM}$ DTT under nitrogen at room temperature overnight. Iodoacetamide was added to this solution to achieve a final concentration of $3.0 \mathrm{mM}$ and incubated at $25^{\circ} \mathrm{C}$ for $15 \mathrm{~min}$ in the dark. The chemical reaction was stopped by adding $7 \mu \mathrm{l} \beta$-mercaptoethanol $(\sim 100 \mathrm{mM}$ final concentration), and by placing the reaction tube in ice. The protein solution was then extensively dialyzed against PBS, $\mathrm{pH} 8.0$ in the dark.

\subsection{CD spectra}

The CD spectra of protein samples were taken with a JASCO J-720 spectropolarimeter (Jasco, Easton, MD). The band width was $2 \mathrm{~nm}$, scan speed $10 \mathrm{~nm} / \mathrm{min}$ and time constant $4 \mathrm{~s}$. Native as well as modified Jun a 1 protein samples in PBS, pH 8.0 were scanned twice at $25{ }^{\circ} \mathrm{C}$ and the resultant spectra were normalized to a minimum value of -1 .

\subsection{Dynamic light scattering}

Dynamic light scattering (DLS) was used to assess the effect of chemical and heat treatment on the apparent size of Jun a 1. Experiments were performed at a protein concentration of 0.1 $\mathrm{mg} / \mathrm{ml}$ in PBS pH 8.0 at $25 \pm 0.2{ }^{\circ} \mathrm{C}$, using a DynaPro-MS/X dynamic light scattering instrument (Protein Solutions Inc.) equipped with an automated temperature control unit. Samples were filtered through $0.1 \mu \mathrm{m}$ Anodisc filters (Whatman) prior to analysis. The data were analyzed, using the program, Dynamics (Protein Solutions Inc.), employing the intensityweighted regularization model.

\subsection{ImmunoCAP assays for human IgE binding and inhibition of binding}

The concentration of IgE anti-Jun a 1 antibodies in each of the serum samples from the mountain cedar-allergic patients were determined by ImmunoCAP assays. The caps were prepared and calibrated by Pharmacia, using native Jun a 1 purified in our lab and five sera from our patients. Aliquots of each of serum were preincubated with native and heat or chemically modified Jun a 1 at $4{ }^{\circ} \mathrm{C}$ for $16 \mathrm{~h}$. A final concentration of Jun a $1 \mathrm{of} 0.25 \mathrm{mg} / \mathrm{ml}$ was chosen based on previous dose-response experiments. Control tubes contained the same serum incubated with the buffer. The residual IgE binding was tested on Jun a 1 caps, as per manufacturer's instructions (Pharmacia). Results were expressed as the percent inhibition of IgE binding to the caps, calculated as follows: $\%$ inhibition $=\left[\left(\right.\right.$ R.U. serum alone $^{-}$

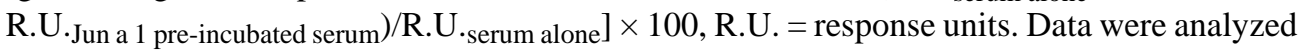
for statistical significance, using Wilcoxon signed rank test for the significance in difference $(\alpha=0.05)$.

\subsection{ELISA assay for binding of mAb KW-S91 to purified Jun a 1}

The relative binding of KW-S91 to native and chemically and heat modified Jun a 1 was assessed in an ELISA assay performed essentially as described previously (Midoro-Horiuti et al., 2006). Briefly, wells of a 96 -well microtiter plate were coated with $3 \mu \mathrm{g} / \mathrm{ml}$ of either purified native Jun a 1 or Jun a 1 modified as described above. The concentration of soluble Jun a 1 in each of the preparations was determined by densitometric analysis of Coomassie-stained SDSPAGE gels. Binding curves were produced by serial dilution of the mAb and detection of the bound fraction, using HRP-conjugated rabbit anti-mouse IgG. The results from the colorimetric enzyme assay were plotted and the relative binding assessed by determining the $\mathrm{mAb}$ concentration that resulted in $50 \%$ of the maximal activity for each Jun a 1 coat. 


\section{Results}

\subsection{CD analyses}

The effects of thermal and chemical denaturation on the secondary structure of Jun a 1, as indicated in their CD spectra between 200 and $260 \mathrm{~nm}$ are shown in Fig. 1. The relative CD spectra of reduced and alkylated Jun a 1 were similar to those of native Jun a 1, indicating that reduction and alkylation of the solvent-exposed disulfide bonds did not grossly change the secondary structure of Jun a 1 . Heat-treated sample showed a slight shift in spectra, indicating that the conditions used $\left(75^{\circ} \mathrm{C}\right.$ for $\left.1 \mathrm{~h}\right)$ induced partial denaturation of Jun a 1 . Guanidine denaturation resulted in a shift in spectrum that suggested a decrease in the relative content of $\alpha$-helical structure and an increase in random coil structure.

\subsection{Dynamic light scattering}

The average Stoke's radii of the Jun a 1 samples are shown in Table 1. The Stoke's radius was significantly increased when guanidine-denatured protein was reduced and acetylated with iodoacetamide, suggesting it had partially unfolded. Guanidine treatment without reductive alkylation and reduction and alkylation without guanidine denaturation did not significantly alter the Stoke's radius of Jun a 1.

\subsection{Effects of treatments on binding of human IgE and mouse mAb KW-S91}

The results of ImmunoCAP inhibition assays comparing native with heat and chemically denatured Jun a 1 as the inhibitors are shown in Fig. 2. Pre-incubation of patient sera with native Jun a 1 inhibited $92 \pm 9 \%$ of IgE binding to caps derivatized with native Jun a 1. Jun a 1 that was treated to reduce and alkylate disulfide bonds, but not exposed to denaturants also inhibited $92 \pm 9 \%$ of IgE binding to the caps. However, Jun a 1 denatured with guanidine only inhibited $69 \pm 1 \%$ and Jun a 1 reduced and alkylated under denaturing condition (guanidine) inhibited $64 \pm 16 \%$ of IgE binding to the caps. Similarly, Jun a 1 denatured by heat only inhibited $65 \pm 11 \%$ of IgE binding. The inhibition of IgE binding by Jun a 1 exposed to guanidine and reductive alkylation or heat denaturation were all significant less than that induced by native Jun a $1(p=0.04)$, but did not differ significantly among these treatments.

The binding of mouse mAb KW-S91 to each preparation of Jun a 1 in the ELISA are shown in Fig. 3. The results indicate that the binding of this antibody was increased by the same treatments that decreased the binding of human IgE binding, suggesting that the display of linear epitope 2 (Midoro-Horiuti et al., 2006) is enhanced by heat and guanidine-induced denaturation of Jun a 1 . This increased binding also indicated that denatured Jun a 1 bound to the ELISA plate at lease as well as the native.

\section{Discussion}

The full display of $\operatorname{IgE}$ epitopes of a number of allergens have been shown to be dependent on their native structures. In fact, the intensely studied allergen, Bet $\mathrm{v} 1$ from birch pollen is said to contain no linear epitopes (Laffer et al., 1996; Visco et al., 1996). Our lab has identified two of the major allergens of mountain cedar pollen, Jun a 1 and Jun a 3 (Midoro-Horiuti et al., 2000). Jun a 1 is the most abundant extractable protein in mountain cedar pollen and dominates the human IgE response to pollen extracts. We recently described four linear IgE epitopes in Jun a 1 (Midoro-Horiuti et al., 2003) and mapped these to regions that are surface exposed, based on homology modeling of this protein. This proposition was confirmed by the high resolution crystal structure of Jun a 1 (Czerwinski et al., 2005), which indicated that each of the regions identified as IgE epitopes are largely solvent-exposed in native Jun a 1.

Interestingly, two of these epitopes reside within a highly conserved region of the parallel $\beta$ - 
helical core of Jun a 1. The other two linear epitopes localize to less ordered regions that form "caps" near each end of the cylindrical structure.

In the current work, we have examined the effects of heat treatment, chemical denaturation and reductive alkylation on the binding of human IgE to Jun a 1. Exposure to $6 \mathrm{M}$ guanidine $\mathrm{HCl}$ (with or without subsequent reducing and alkylating conditions) and heating to $75^{\circ} \mathrm{C}$ for $1 \mathrm{~h}$ significantly reduced the binding of IgE, thus suggesting that Jun a 1 also has conformational as well as linear epitopes.

Exposure of Jun a 1 to reducing and alkylating conditions alone did not affect the binding of human IgE or the mouse mAb to Jun a 1. This finding is somewhat surprising, since two $\left(\mathrm{Cys}^{7}-\mathrm{Cys}^{24}\right.$ and $\mathrm{Cys}^{285}$-Cys ${ }^{291}$ ) of the three-disulfide bonds are surface exposed and thus potentially susceptible to this treatment (Czerwinski et al., 2005). The Cys ${ }^{7} \mathrm{Cys}^{24}$ disulfidebridge helps to hold together the N-terminus helix-turn-helix motif. If our treatment was successful in reducing this bridge, this would suggest that either there are no epitopes in that regions or that the disulfide bond may not be required to stabilize a conformational epitope within that large loop. Similarly, reduction of $\mathrm{Cys}^{285}{ }^{28} \mathrm{Cys}^{291}$ disulfide bond, which stabilizes a $\Omega$ loop near the C-terminus of the molecule, did not destroy any conformational epitopes that might reside in those regions. These findings are consistent with the findings that exposing Jun a 1 to reducing and alkylating conditions alone did not result in measurable biophysical changes in the molecule.

In contrast, the finding that denaturing Jun a 1 with guanidine resulted in substantial loss of IgE binding provides evidence for one or more conformational epitopes in Jun a 1, since this treatment is not likely to disrupt epitopes within linear amino acid sequences, glycans or glycopeptide structures. In order to confirm that guanidine treatment did not disrupt linear epitopes of Jun a 1, we examined the binding of a mouse $\mathrm{mAb}$, which reacts with the linear epitope we designated as epitope 2 (Midoro-Horiuti et al., 2006). The display of the epitope 2 region, which resides within the $\beta$-sheet-rich core of the Jun a 1 molecule, was actually increased by the treatment with guanidine.

Guanidine treatment also caused a shift in the $\mathrm{CD}$ spectrum, consistent with a relative decrease in $\alpha$-helical structure and gain of random structure. Together these findings suggest that $\alpha$ helices are likely candidates for one or more conformational epitopes in Jun a 1. IgE epitopes in other allergens have been found in $\alpha$-helices (Mine et al., 2003; Rafnar et al., 1998; Vrtala et al., 1999; Wiche et al., 2005). When Jun a 1 was reduced and alkylated in the presence of guanidine, there was no further decrease in IgE binding, suggesting that neither disulfide bond nor the free sulfhydryl group are required for any conformational epitopes in Jun a 1 . The finding that reductive alkylation under denaturing conditions caused a significant increase in the Stoke's radius, as measured by dynamic light scattering, indicates that one or more of the disulfide bonds were broken by this treatment, thereby relaxing the structure and increasing its apparent size.

Interestingly, heating Jun a 1 at $75^{\circ} \mathrm{C}$ for $1 \mathrm{~h}$ reduced $\mathrm{IgE}$ binding to about the same extent as chemical denaturation. The proportion of loss in IgE binding varied from 18 to $55 \%$ among the 5 sera from mountain cedar-sensitive individual tested. The finding that the majority of the $\operatorname{IgE}$ binding was preserved after chemical and thermal denaturation suggests that the regions of Jun a 1 containing the linear IgE epitopes (e.g. as the four we have described) retain their surface display after the protein is exposed to these denaturing conditions. This proposition was confirmed by the finding that denaturing Jun a 1 actually increased the binding of a mAb $\mathrm{KW}-\mathrm{S} 91$ to one of the linear epitopes. In fact, if denaturation of Jun a 1 increases the binding of human $\operatorname{IgE}$ to one or more of these linear epitopes, the actual extent of $\operatorname{IgE}$ binding to conformational epitopes may be underestimated by our assays. 
It is interesting to speculate on how the dominance of linear epitopes and the stability of their display on the surface of Jun a 1 contribute to the potency of this allergen, to which a large proportion of the exposed populations become sensitized (Midoro-Horiuti, 1992; Schwietz et al., 2000). Further studies of the progression and extent of the sensitization to individual epitopes should provide a better understanding of the role of different types of epitopes in the sensitization to allergenic proteins. This type of analysis may lead to better diagnostic and prognostic testing and the design of safe and effective treatment of hypersensitivity to cedar pollen and perhaps other allergens.

\section{Acknowledgements}

We wish to thank Dr. Julius van Bavel for providing sera from patients with mountain cedar hypersensitivity and Dr. Joerg Roesgen and D. Wayne Bolen for CD and Dynamic Light Scattering analysis and Dr. Matthew Auton. This work was supported by Advanced Technology Program from Texas Higher Education Coordinating Board (R.M.G.), Parker B. Francis Fellowship in Pulmonary Research from Francis Families Foundation (T.M.H.), and R01 AI052428 (R.M.G.) and K08 AI055792 grant (T.M.H.) from NIAID.

\section{References}

Czerwinski EW, Midoro-Horiuti T, White MA, Brooks EG, Goldblum RM. Crystal structure of Jun a 1, the major cedar pollen allergen from Juniperus ashei, reveals parallel beta-helical core. J Biol Chem 2005;280:3740-3746. [PubMed: 15539389]

Gajhede M, Osmark P, Poulsen FM, Ipsen H, Larsen JN, Joost van Neerven RJ, Schou C, Lowenstein $\mathrm{H}$, Spangfort MD. X-ray and NMR structure of Bet v 1, the origin of birch pollen allergy. Nat Struct Biol 1996;3:1040-1045. [PubMed: 8946858]

Imoto, T.; Yamada, H. Chemical Modification. IRL Press; New York: 1989.

Laffer S, Vangelista L, Steinberger P, Kraft D, Pastore A, Valenta R. Molecular characterization of Bip 1 , a monoclonal antibody that modulates IgE binding to birch pollen allergen, Bet $\mathrm{v} 1$. J Immunol 1996;157:4953-4962. [PubMed: 8943401]

Law AW, Reed SD, Sundy JS, Schulman KA. Direct costs of allergic rhinitis in the United States: estimates from the 1996 Medical Expenditure Panel Survey. J Allergy Clin Immunol 2003;111:296300. [PubMed: 12589348]

Lombardero M, Heymann PW, Platts-Mills TA, Fox JW, Chapman MD. Conformational stability of B cell epitopes on group I and group II Dermatophagoides spp. allergens Effect of thermal and chemical denaturation on the binding of murine IgG and human IgE antibodies. J Immunol 1990;144:13531360. [PubMed: 1689351]

Midoro-Horiuti T. Evaluation of allergenicity of the extract of Japanese juniper pollen reacting to sera from asthmatic children - by the methods of enzyme-linked immunosorbent assay and immunoblotting. Jpn J Allergol 1992;41:1459-1465.

Midoro-Horiuti T, Goldblum RM, Kurosky A, Goetz DW, Brooks EG. Isolation and characterization of the mountain cedar (Juniperus ashei) pollen major allergen, Jun a 1. J Allergy Clin Immunol 1999a; 104:608-612. [PubMed: 10482835]

Midoro-Horiuti T, Goldblum RM, Kurosky A, Wood TG, Schein CH, Brooks EG. Molecular cloning of the mountain cedar (Juniperus ashei) pollen major allergen, Jun a 1. J Allergy Clin Immunol 1999b; 104:613-617. [PubMed: 10482836]

Midoro-Horiuti T, Goldblum RM, Kurosky A, Wood TG, Brooks EG. Variable expression of pathogenesis-related protein allergen in mountain cedar (Juniperus ashei) pollen. J Immunol 2000;164:2188-2192. [PubMed: 10657673]

Midoro-Horiuti T, Mathura V, Schein CH, Braun W, Chin CCQ, Yu S, Watanabe M, Lee JC, Brooks EG, Goldblum RM. Major IgE epitopes of mountain cedar pollen allergen Jun a 1 are near the pectate lyase catalytic site. Mol Immunol 2003;40:555-562. [PubMed: 14563374]

Midoro-Horiuti T, Schein CH, Mathura V, Braun W, Czerwinski EW, Togawa A, Kondo Y, Oka T, Watanabe M, Goldblum RM. Structural basis for epitope sharing between group 1 allergens of cedar pollen. Mol Immunol 2006;43:509-518. [PubMed: 15975657] 
Mine Y, Sasaki E, Zhang JW. Reduction of antigenicity and allergenicity of genetically modified egg white allergen, ovomucoid third domain. Biochem Biophys Res Commun 2003;302:133-137. [PubMed: 12593859]

Neudecker P, Lehmann K, Nerkamp J, Haase T, Wangorsch A, Fotisch K, Hoffmann S, Rosch P, Vieths $\mathrm{S}$, Scheurer S. Mutational epitope analysis of Pru av 1 and Api g 1, the major allergens of cherry (Prunus avium) and celery (Apium graveolens): correlating IgE reactivity with three-dimensional structure. Biochem J 2003;376:97-107. [PubMed: 12943529]

Rafnar T, Brummet ME, Bassolino-Klimas D, Metzler WJ, Marsh DG. Analysis of the three-dimensional antigenic structure of giant ragweed allergen, Amb t 5. Mol Immunol 1998;35:459-467. [PubMed: 9798650]

Reid MJ, Nish WA, Whisman BA, Goetz DW, Hylander RD, Parker WA Jr, Freeman TM. HLA-DR4associated nonresponsiveness to mountain-cedar allergen. J Allergy Clin Immunol 1992;89:593-598. [PubMed: 1740588]

Romagnani S. The increased prevalence of allergy and the hygiene hypothesis: missing immune deviation, reduced immune suppression, or both? Immunology 2004;112:352-363. [PubMed: 15196202]

Scheiner O, Kraft D. Basic and practical aspects of recombinant allergens. Allergy 1995;50:384-391. [PubMed: 7573826]

Schramm G, Bufe A, Petersen A, Haas H, Merget R, Schlaak M, Becker WM. Discontinuous IgE-binding epitopes contain multiple continuous epitope regions: results of an epitope mapping on recombinant Hol 1 5, a major allergen from velvet grass pollen. Clin Exp Allergy 2001;31:331-341. [PubMed: $11251635]$

Schramm G, Petersen A, Bufe A, Schlaak M, Becker WM. Identification and characterization of the major allergens of velvet grass (Holcus lanatus), Hol 11 and Hol 1 5. Int Arch Allergy Immunol 1996;110:354-363. [PubMed: 8768803]

Schwietz LA, Goetz DW, Whisman BA, Reid MJ. Cross-reactivity among conifer pollens. Ann Allergy Asth Immunol 2000;84:87-93.

Smith AM, Chapman MD. Reduction in IgE binding to allergen variants generated by site-directed mutagenesis: contribution of disulfide bonds to the antigenic structure of the major house dust mite allergen Der p 2. Mol Immunol 1996;33:399-405. [PubMed: 8676891]

Takahashi Y, Nagoya T, Watanabe M, Inouye S, Sakaguchi M, Katagiri S. A new method of counting airborne Japanese cedar (Cryptomeria japonica) pollen allergens by immunoblotting. Allergy Eur J Allergy Clin Immunol 1993;48:94-98.

Takai T, Yokota T, Yasue M, Nishiyama C, Yuuki T, Mori A, Okudaira H, Okumura Y. Engineering of the major house dust mite allergen Der $\mathrm{f} 2$ for allergen-specific immunotherapy. Nat Biotechnol 1997;15:754-758. [PubMed: 9255789]

Visco V, Dolecek C, Denepoux S, Le Mao J, Guret C, Rousset F, Guinnepain MT, Kraft D, Valenta R, Weyer A, Banchereau J, Labecque S. Human IgG monoclonal antibodies that modulate the binding of specific IgE to birch pollen Bet v 1. J Immunol 1996;157:956-962. [PubMed: 8752951]

Vrtala S, Fischer S, Grote M, Vangelista L, Pastore A, Sperr WR, Valent P, Reichelt R, Kraft D, Valenta R. Molecular, immunological, and structural characterization of $\mathrm{Phl} \mathrm{p} \mathrm{6,} \mathrm{a} \mathrm{major} \mathrm{allergen} \mathrm{and} \mathrm{P}$ particle-associated protein from Timothy grass (Phleum pratense) pollen. J Immunol 1999;163:5489-5496. [PubMed: 10553075]

Vrtala S, Hirtenlehner K, Vangelista L, Pastore A, Eichler HG, Sperr WR, Valent P, Ebner C, Kraft D, Valenta R. Conversion of the major birch pollen allergen, Bet v 1, into two nonanaphylactic T cell epitope-containing fragments: candidates for a novel form of specific immunotherapy. J Clin Invest 1997;99:1673-1681. [PubMed: 9120011]

Weerd ND, Bhalla PL, Singh MB. Effect of cysteine mutagenesis on human IgE reactivity of recombinants forms of the major rye grass pollen allergen Lol p 1. Allergol Int 2003;52:183-190.

Wiche R, Gubesch M, Konig H, Fotisch K, Hoffmann A, Wangorsch A, Scheurer S, Vieths S. Molecular basis of pollen-related food allergy: identification of a second cross-reactive IgE epitope on Pru av 1, the major cherry (Prunus avium) allergen. Biochem J 2005;385:319-327. [PubMed: 15330760]

Yang M, Ferreon AC, Bolen DW. Structural thermodynamics of a random coil protein in guanidine hydrochloride. Proteins Suppl 2000;4:44-49. 


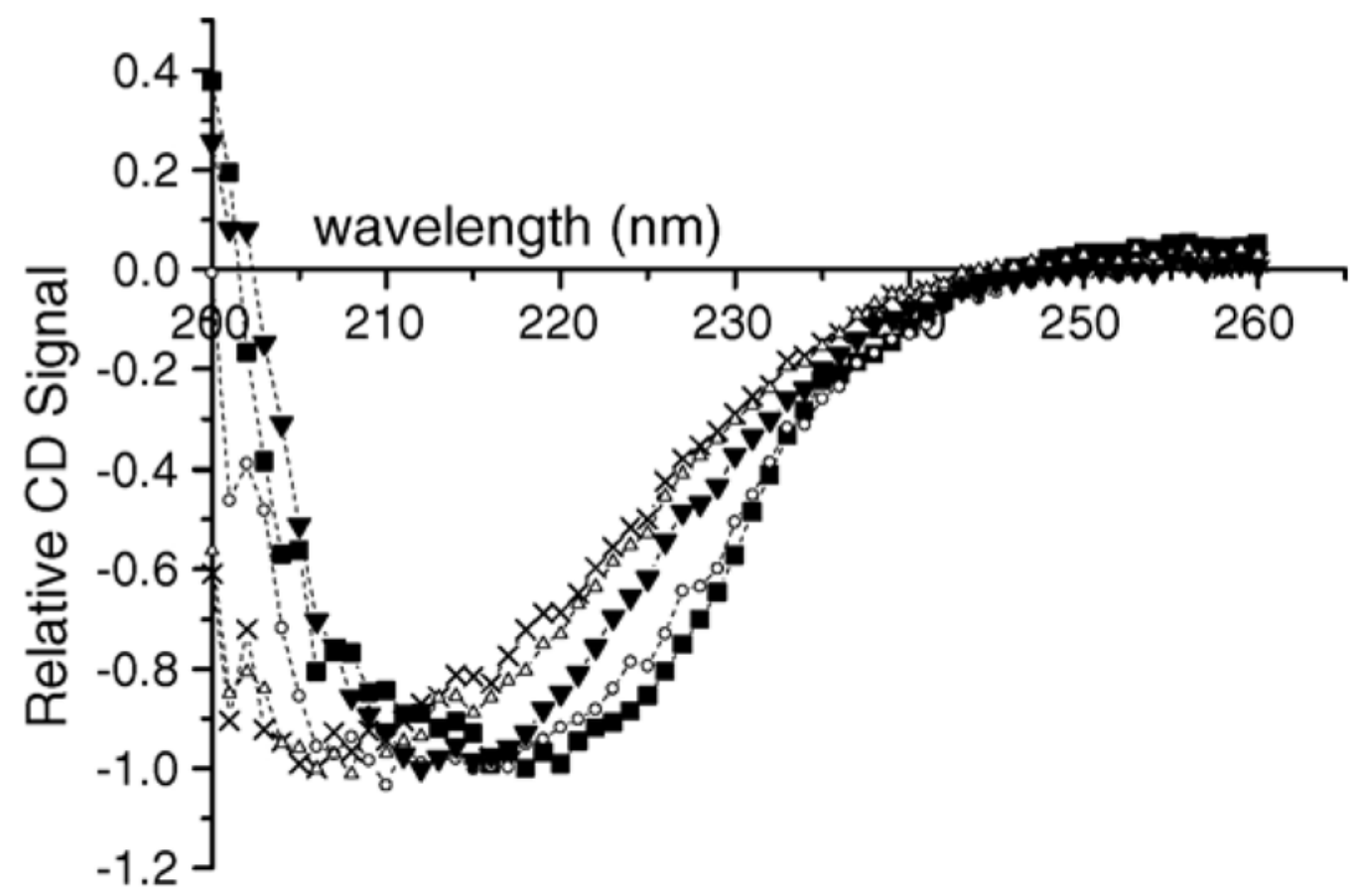

Fig. 1.

$\mathrm{CD}$ spectra of native and denatured Jun a 1 samples. $\mathrm{R} / \mathrm{A}=$ reduced and alkylated, $\mathrm{Gu}=$ guanidine denatured, $\mathrm{Gu}-\mathrm{R} / \mathrm{A}=$ reduced and alkylated after guanidine denaturation, Heat = Jun a 1 heated at $75^{\circ} \mathrm{C}$ for $1 \mathrm{~h}$. Symbols are as follows: $(\boldsymbol{\bullet})=$ native, $(\bullet)=\mathrm{R} / \mathrm{A},(\Delta)=\mathrm{Gu}$, $(\mathbf{X})=\mathrm{Gu}-\mathrm{R} / \mathrm{A},(\boldsymbol{\nabla})=$ Heat. 


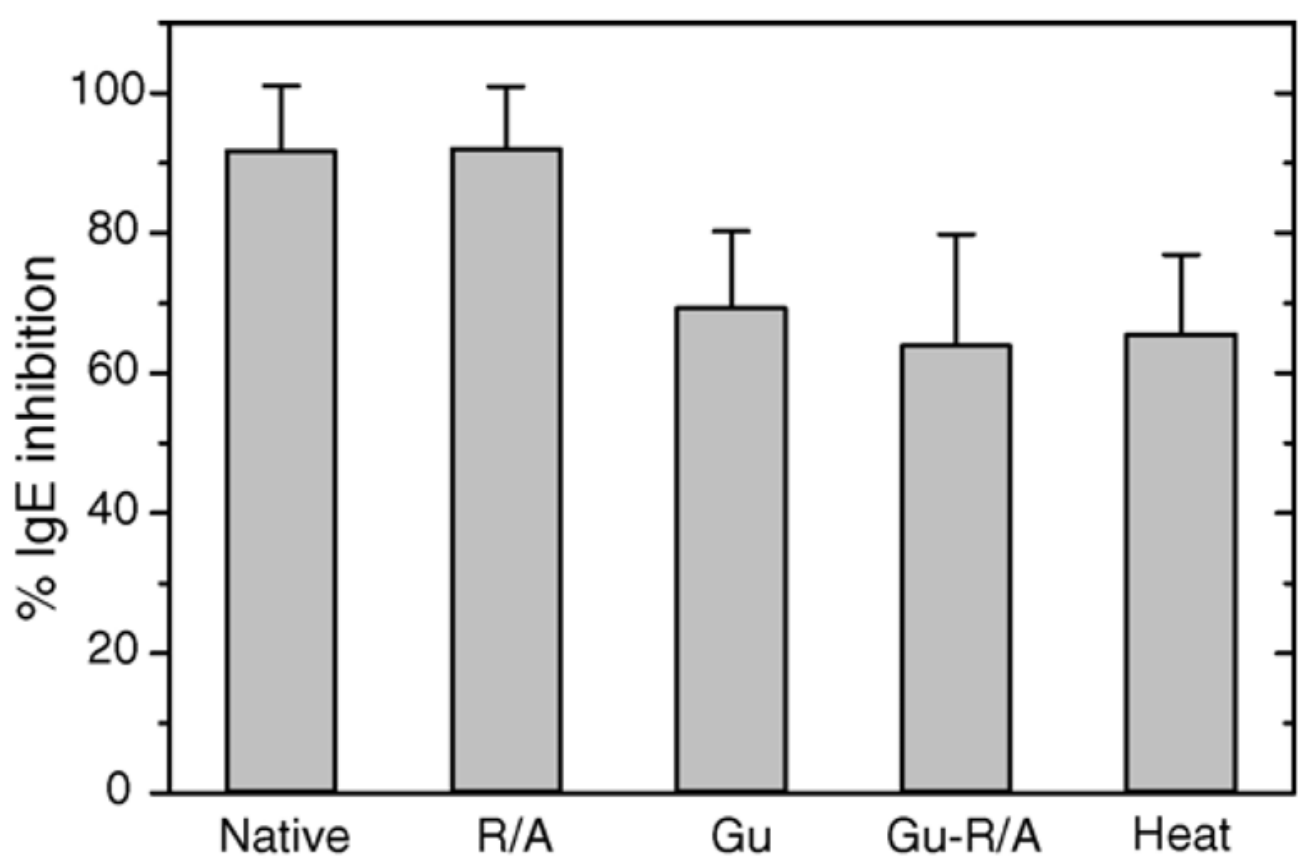

Fig. 2.

ImmunoCAP inhibition assays. ImmunoCAP IgE inhibition of purified Jun a 1 by native and treated samples of Jun a 1 protein. $\mathrm{R} / \mathrm{A}=$ reduced and alkylated, $\mathrm{Gu}=$ guanidine denatured, $\mathrm{Gu}-\mathrm{R} / \mathrm{A}=$ reduced and alkylated after guanidine denaturation, Heat $=$ protein heated at $75{ }^{\circ} \mathrm{C}$ for $1 \mathrm{~h}$. Reduced and alkylated protein was similar to native protein in inhibiting IgE as shown by Wilcoxon signed-rank test $(p=0.4652)$. For $\mathrm{Gu}, \mathrm{Gu}-\mathrm{R} / \mathrm{A}$ and heat-treated samples, there was significant difference between native and treated samples $(p=0.04311, \alpha=0.05)$. 


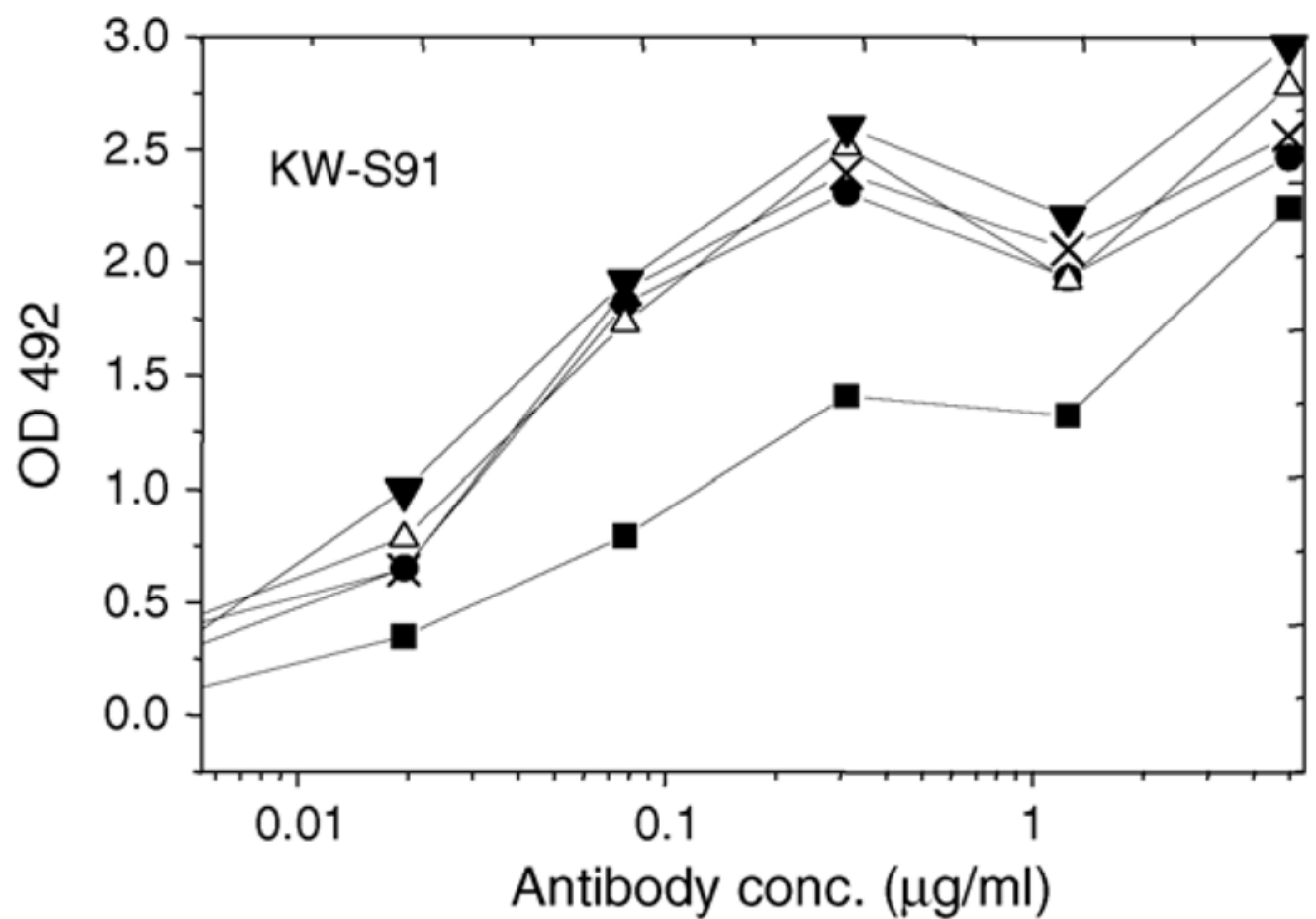

Fig. 3.

The binding of mouse mAb KW-S91 to each preparation of Jun a 1 in the ELISA. Native Jun a 1 , untreated or treated as indicated, was bound to wells and then incubated with varying concentrations of the monoclonal IgG, KW-S91. Binding efficiency was measured colorimetrically after incubation with rabbit-anti-mouse IgG-HRP conjugate. KW-S91 mAb binding in all the samples were significantly increased after heat and chemical treatment of Jun a $1 .(\boldsymbol{\square})=$ Native, $(\bullet)=\mathrm{R} / \mathrm{A},(\Delta)=\mathrm{Gu},(\mathbf{X})=\mathrm{Gu}-\mathrm{R} / \mathrm{A},(\boldsymbol{\nabla})=$ Heat. 
Table 1

Stoke's radius of native and denatured Jun a 1

\begin{tabular}{ll}
\hline Jun a 1 sample & Stoke's radius \pm S.D. $(\mathbf{n m})$ \\
\hline Native & $4.18 \pm 0.57$ \\
Gu & $4.61 \pm 0.73$ \\
Gu-DTT/IAA & $5.99 \pm 0.67$ \\
Heat & $4.81 \pm 0.37$ \\
\hline
\end{tabular}

Gu: incubated in $6 \mathrm{M}$ guanidine buffer, Gu-DTT/IAA: reduced and alkylated in $6 \mathrm{M}$ guanidine buffer, heat: heat denatured. 